\title{
Spatial variations in heat at the base of the Antarctic ice sheet from analysis of the thermal regime above subglacial lakes
}

\author{
Martin J. Siegert and Julian A. Dowdeswell \\ Centre for Glaciology, Institule of Earth Studies, University of Wales, Aberystwylh, Dyfed Sr23 3DB, Wales
}

\begin{abstract}
Antarctic subglacial lakes provide an important boundary condition for thermal analysis of the ice sheet in that the basal ice temperature over lakes may be assumed to be at the pressure-melting point. We have used a one-dimensional vertical heat-transfer equation to determine theoretical temperature values for the ice-sheet base above 77 subglacial lakes identified from airborne radio-echo-sounding data covering $50 \%$ of Antarctica. Variations in our temperature results to below the pressure-melting temperature over lakes are due to either our estimate of the geothermal heat flux or a neglect of heat derived from (a) internal ice deformation and (b) basal sliding, in the thermal model. Our results indicate that, when the geothermal heat flux is set at $54 \mathrm{~mW} \mathrm{~m}^{-2}$, the ice-sheet base above $70 \%$ of the known Antarctic subglacial lakes is calculated to be at the pressure-melting value. These lakes are located mainly around Dome C, Ridge B and Vostok station. For the ice sheet above subglacial lakes located hundreds of kilometres from the ice divide, using the same thermal model, loss of heat due to vertical advection is calculated to be relatively high. In such regions, if the ice-sheet base is at the pressure-melting point, heat lost due to vertical advection must be supplemented by heat from other sources. For the three lakes beneath Terre Adélie and George V Land, for instance, the basal thermal gradient calculated to produce pressure melting at the ice-sheet base is equivalent to $1.5-2$ times the value obtained when $54 \mathrm{~mW} \mathrm{~m}^{-2}$ of geothermal heat is used as the sole basal thermal component. We suggest that, as distance from the ice divide increases, so too does the amount of heat due to internal ice deformation and basal sliding. Moreover, by considering the ice-sheet basal thermal characteristics above subglacial lakes which lie on the same ice flowline, we demonstrate empirically that the heat due to these horizontal ice-motion terms varies pseudo-exponentially with distance from the ice divide. The location along a flowline where a rapid increase in the basal heat gradient is calculated may correspond to the onset of large-scale basal sliding.
\end{abstract}

\section{INTRODUCTION}

Subglacial lakes have been identified at 77 locations within Antarctica from airborne radio-echo-sounding (RES) data covering over $50 \%$ of the ice sheet Oswald and Robin, 1973; Robin and others, 1977; McIntyre, 1983; Siegert and others, in press). Seismic data indicate that, close to Vostok station, the water depth of a large $230 \mathrm{~km}$ by $50 \mathrm{~km}$ subglacial lake is about $500 \mathrm{~m}$ (Kapitsa and others, 1996). The existence of large volumes of water beneath the East Antarctic ice sheet has significant consequences for analyzing the thermal regime of the ice sheet. The presence of subglacial lakes indicates that, in the region of the ice sheet over and adjacent to the lake, the temperature of the ice-sheet base is at the pressuremelting point.

Basal ice-sheet temperatures are controlled by a number of parameters including ice thickness, ice-sheet surface temperature and accumulation rate, heat transported through horizontal advection of ice, the basal heat gradient (the sum of geothermal heat flux and heat produced from basal sliding) and heat derived from internal ice deformation. The basal heat gradient is dependent on the flow at (or effectively close to) the icesheet base, and its magnitude will therefore increase with distance from the ice divide as ice-sheet velocity increases. This paper aims to determine numerical information on the spatial distribution and magnitude of heat derived at the ice-sheet base due to (i) geothermal sources, (ii) internal ice deformation and basal sliding (or, collectively, horizontal ice-motion terms) and (iii) heat transported by the horizontal advection of ice.

An inspection of the spatial distribution of lakes over the Antarctic continent (Fig. 1) indicates that approximately $43 \%$ of those found are located within $100 \mathrm{~km}$ of an ice divide in the direction of ice flow (Siegert and others, in press). Furthermore, a large concentration of Antarctic subglacial lakes $(\sim 78 \%)$ lies beneath major ice domes at Dome C, Ridge B and Titan Dome (Fig. 1). However, there are seven subglacial lakes (representing $9 \%$ of the known total), at Terre Adélie and west of the Transantarctic Mountains, that are situated over $400 \mathrm{~km}$ 


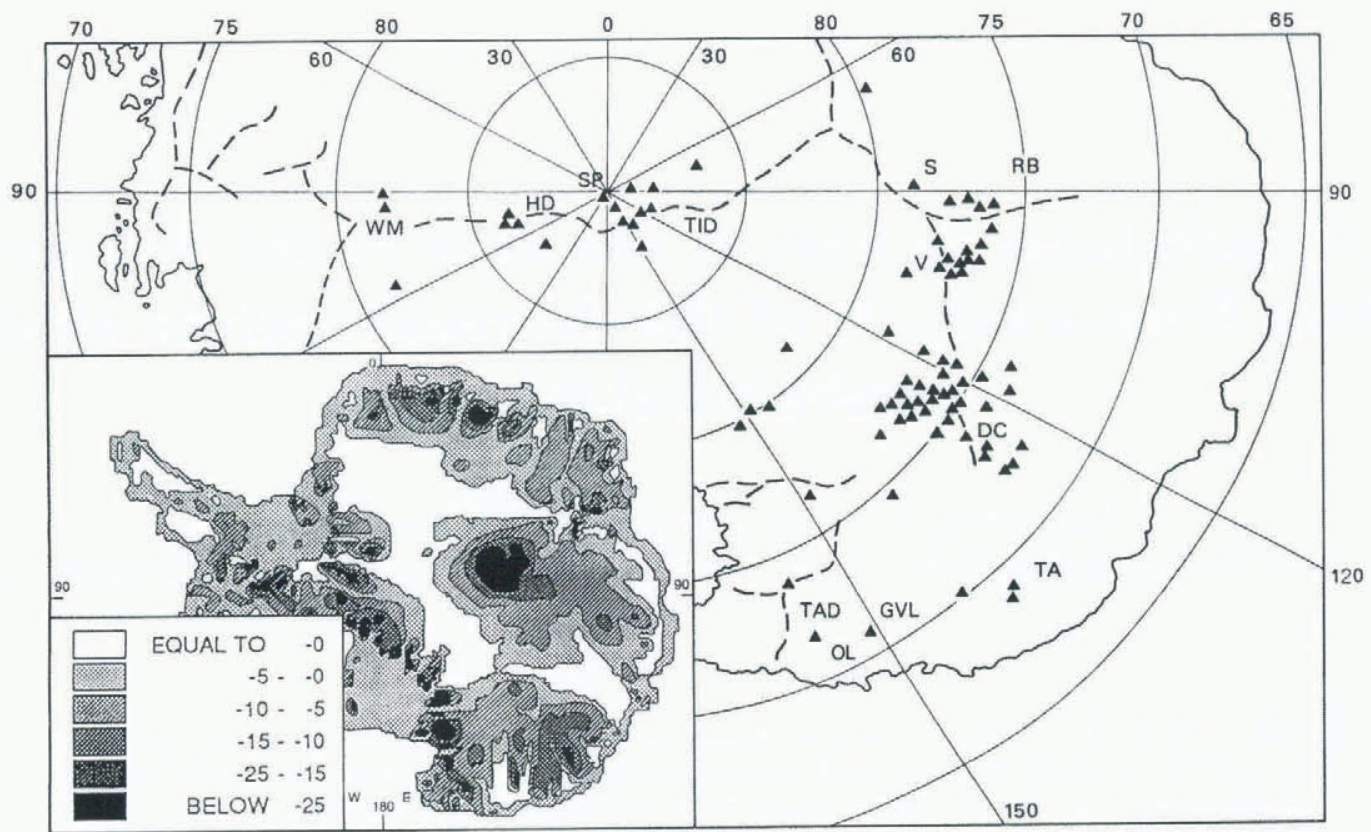

Fig. 1. (a) Locations of subglacial lakes determined from the SPRI-NSF-TUD airborne RES data (after Siegert and others, in press). Ice divides are illustrated as dashed lines. Abbreviations to place-names are as follows: DC, Dome C; GVL, George V Land; HD, Hercules Dome; OL, Oates Land, RB, Ridge B; S, Sovetskaya station; SP, South Pole; TA, Terre Adélie; TAD, Talos Dome; TID, Titan Dome; V, Vostok station; WM, Whitmore Mountains. (b) Calculated basal temperatures from a three-dimensional thermomechanical ice-sheet model of the Antarctic ice sheet (from Huybrechts, 1992). The geothermal heat flux used to determine the basal temperatures was set at $54.6 \mathrm{~mW} \mathrm{~m}^{-2}$.

along the line of ice flow from the ice divide (Fig. 1). The direction of ice motion was determined using information on ice-sheet surface morphology (Drewry, 1983), assuming that the direction of ice flow is perpendicular to icesurface contours.

Recent three-dimensional thermomechanical glaciological modelling of the Antarctic ice sheet indicates that, under contemporary environmental conditions, and using a geothermal heat flux of $54.6 \mathrm{~mW} \mathrm{~m}^{-2}$, several regions of the ice-sheet base, corresponding to the proximity of the calculated ice divides, are at the pressure-melting point (Huybrechts, 1992). However, although the glaciological model used by Huybrechts is one of the most sophisticated of its kind, the temperature in several regions of the modelled ice-sheet base, where subglacial lakes are known to exist, was calculated to be below the pressure-melting value (Fig. 1b). For example, around Ridge B, where up to six subglacial lakes have been identified, Huybrechts' glaciological model calculated the temperature of the icesheet base at around $-5^{\circ} \mathrm{C}$ (Fig. 1b).

A general source of error in ice-sheet models is derived from the smoothed bedrock topography that is used as model input. As a consequence, the ice thickness that is calculated by glaciological models, when the present icesurface elevation is determined, will be prone to similar errors. In the case of Huybrechts' (1992) model, the Antarctic bedrock-topography input was in the form of a finite-difference grid composed of $1600 \mathrm{~km}^{2}$ sized $(40 \mathrm{~km}$ by $40 \mathrm{~km}$ ) cells, adapted from maps compiled by Drewry (1983). However, due to the smoothing that occurs when a continuous topography is represented as a series of individual cells, there are discrepancies between the icethickness array, representing the finite-difference grid, and direct point measurements from both Drewry's maps and information gathered from the raw RES data.

The ice-sheet thickness is an important parameter in the calculation of temperature at the ice-sheet base. It is therefore useful to calculate the thermal regime of the ice sheet above each known subglacial lake, using the RESmeasured ice thickness as input to the thermal equations. Subsequently, the accuracy of our numerical results will not suffer as a consequence of bedrock smoothing.

\section{BASAL ICE-SHEET TEMPERATURE CALCULATION}

We assume that, since a large proportion of subglacial lakes are known to occur at or near an ice divide (Siegert and others, in press), a simple Robin-type steady-state thermal model is applicable (Robin, 1955). Consequently, we do not account for temperature variations at the base of the Antarctic ice sheet caused by climate change during, for example, the early Holocene (Whillans, 1978; Jenssen and Campbell, 1983). The equation used to calculate the basal temperature is:

$$
T_{\mathrm{B}}=T_{\mathrm{S}}-\frac{\sqrt{\pi}}{2} l\left(\frac{\mathrm{d} T}{\mathrm{~d} z}\right)_{\mathrm{B}} \operatorname{erf}(h / l)
$$

where

$$
\begin{aligned}
\operatorname{erf}(z) & =\frac{2}{\sqrt{\pi}} \int_{0}^{z} \exp \left(-y^{2}\right) \mathrm{d} y \\
l & =\sqrt{\frac{2 k h}{b}}
\end{aligned}
$$

and

$$
\left(\frac{\mathrm{d} T}{\mathrm{~d} z}\right)_{\mathrm{B}}=-\frac{\Lambda_{\text {geo }}}{K} .
$$


Symbols used in the above equations are defined as follows: $T_{\mathrm{B}}$ is the basal temperature of the ice sheet $\left({ }^{\circ} \mathrm{C}\right)$; $T_{\mathrm{S}}$ is the mean annual surface temperature of the ice sheet $\left({ }^{\circ} \mathrm{C}\right) ; z$ is the coordinate in the vertical direction, positive upwards and zero at the ice-sheet base; $h$ is the ice thickness above the subglacial lake $(\mathrm{m}) ; b$ is the mean annual surface accumulation of the ice sheet above the lake $\left(\right.$ m year $\left.^{-1}\right) ; k$ is the thermal diffusivity of ice $\left(36.3 \mathrm{~m}^{2}\right.$ year $\left.^{-1}\right) ; K$ is the thermal conductivity of ice $\left(2.1 \mathrm{~W} \mathrm{~m}^{-1}{ }^{\circ} \mathrm{C}^{-1}\right)$; and $\Lambda_{\text {geo }}$ is the Earth's geothermal heat flux $\left(54 \mathrm{~mW} \mathrm{~m}^{-2}\right.$ unless stated otherwise).

Equation (4) represents the basal heat gradient caused by the flux of geothermal heat. This equation is relevant only at the ice divide, where horizontal ice motion is minimal. However, away from the ice divide, extra heat terms associated with horizontal ice advection, internal ice deformation and basal sliding will result in more heat at the base of the ice sheet than that calculated in Equation (4). By adjusting the basal heat gradient to account for the extra heat terms at the ice-sheet base, we calculated an "effective" basal heat gradient, which we can then substitute in Equation (1).

The pressure-melting temperature $\left(T_{\mathrm{pmp}}\right)$ of pure ice, in ${ }^{\circ}$, is given by:

$$
T_{\text {pmp }}=0-\frac{h}{1149}
$$

which corresponds to a Clausius-Clapeyron gradient of $8.7 \times 10^{4}{ }^{\circ} \mathrm{Cm}^{-1}$ (Paterson, 1994).

Equation (1) holds only if the basal temperature is at or below the pressure-melting point. If the theoretical basal temperature determined from Equation (1) is higher than the pressure-melting point, the basal temperature recorded is equivalent to the pressure-melting temperature.

The simple steady-state thermal model used in this study is one of several that may be used to determine the temperature at the base of an ice sheet. However, it should be noted that these models often provide conflicting temperature values at the ice-sheet base (e.g. Paterson, 1994). We consider, therefore, that the relative variation in basal temperatures determined by Equation (1), and their spatial distribution beneath the ice sheet, are as important to this study as the absolute basal temperatures calculated for ice above each lake. We note also that, since the Antarctic ice sheet is not in complete steady state, our assumption of steady state may cause basal temperature calculations to be too high. Subsequently, due to the simple method by which we calculate the effective basal heat gradient and basal temperatures, we acknowledge that the results presented are, at best, semi-quantitative in nature.

\section{MODEL INPUTS}

The thermal model requires inputs of mean annual surface accumulation $(b)$ and surface temperature $\left(T_{\mathrm{S}}\right)$, basal temperature $\left(T_{\mathrm{B}}\right)$, basal heat gradient derived from the flux of geothermal heat $\left(\Lambda_{\text {geo }}\right)$, and ice thickness $(h)$. The ice thickness above a subglacial lake can be measured directly from the time-dependent raw RES data (timecontinuous "Z-scope" or spot-measurement "A-scope"), assuming a $60 \mathrm{MHz}$ radio-wave velocity in ice of
$1.69 \times 10^{8} \mathrm{~m} \mathrm{~s}^{-1}$ (Bogorodskiy and others, 1985). We have calculated the ice thickness above each lake from our own independent measurements of the raw Z-scope data, held at the Scott Polar Research Institute, University of Cambridge, which are accurate to within $1.5 \%$.

We assume that the surface air temperature approximates the surface temperature of the ice sheet since, in the Antarctic ice sheet, the surface air temperature is generally within $1{ }^{\circ} \mathrm{C}$ of the firn temperature at $10 \mathrm{~m}$ depth (Loewe, 1970). Thus, the surface temperature of the ice sheet can be obtained from maps of mean annual air temperature, determined from field measurements (Robin, 1983; Fig. 2a).

Surface accumulation on the ice sheet above each lake was obtained from a map of accumulation, interpolated from direct field measurements (Giovinetto and Bentley, 1985; Fig. 2b). The reliability of the contours, interpolated between the field data points, has been enhanced in recent years, after a detailed numerical modelling study of the Antarctic climate yielded results similar to those measured in the field (Fortuin and Oerlemans, $1990)$.

The geothermal heat flux used in this study, $54 \mathrm{~mW}$ $\mathrm{m}^{-2}$ unless stated otherwise, represents the approximate mean value of the Earth's surface heat flux, and is similar to that used by Huybrechts (1992) in recent glaciological modelling studies of the ice sheet.

However, the geothermal heat flux varies globally between about 40 and $90 \mathrm{~mW} \mathrm{~m}^{-2}$ (e.g. Stacey, 1977). It is likely, therefore, that the actual value of the geothermal heat flux may vary spatially beneath the Antarctic ice sheet. In order to account for (i) the uncertainty in the value of the geothermal input to the thermal equation, (ii) heat generated at the ice-sheet base due to horizontal ice-motion terms (internal ice deformation and basal sliding), and (iii) heat transported through horizontal advection of ice, the basal heat-gradient parameter within Equation (1) is varied (thus producing an effective basal heat gradient), with other variables kept at constant values. Subsequent results thus provide a sensitivity experiment on the relation between the ice-sheet basal temperature above subglacial lakes and the effective basal heat gradient.

The calculation procedure adopted in this study is detailed below. Essentially, Equation (1) is solved for (1) $T_{\mathrm{B}}$, in order to derive the basal temperature for when the geothermal heat flux is $54 \mathrm{~mW} \mathrm{~m}^{-2}$, and (2) the basal heat gradient (Equation (4)), assuming that $T_{\mathrm{B}}$ is at the pressure-melting value. Specifically, if the temperature above a subglacial lake was initially calculated to be below the pressure-melting value (when $54 \mathrm{~mW} \mathrm{~m}^{-2}$ is used as the geothermal parameter) then extra heat, derived from geothermal and/or other effective basal heat-gradient terms, is required in Equation (1). We account for this extra heat by altering the geothermal heat input in Equation (4), to a minimum value that yields pressure melting at the ice-sheet base in Equation (1). In performing this procedure, we calculate values for the effective basal heat gradient in terms of the equivalent geothermal heat input (i.e., the adjusted geothermal heat can be thought of as a surrogate for the effective basal heat gradient). This new basal heat gradient, particular for each subglacial lake, is then recorded. 

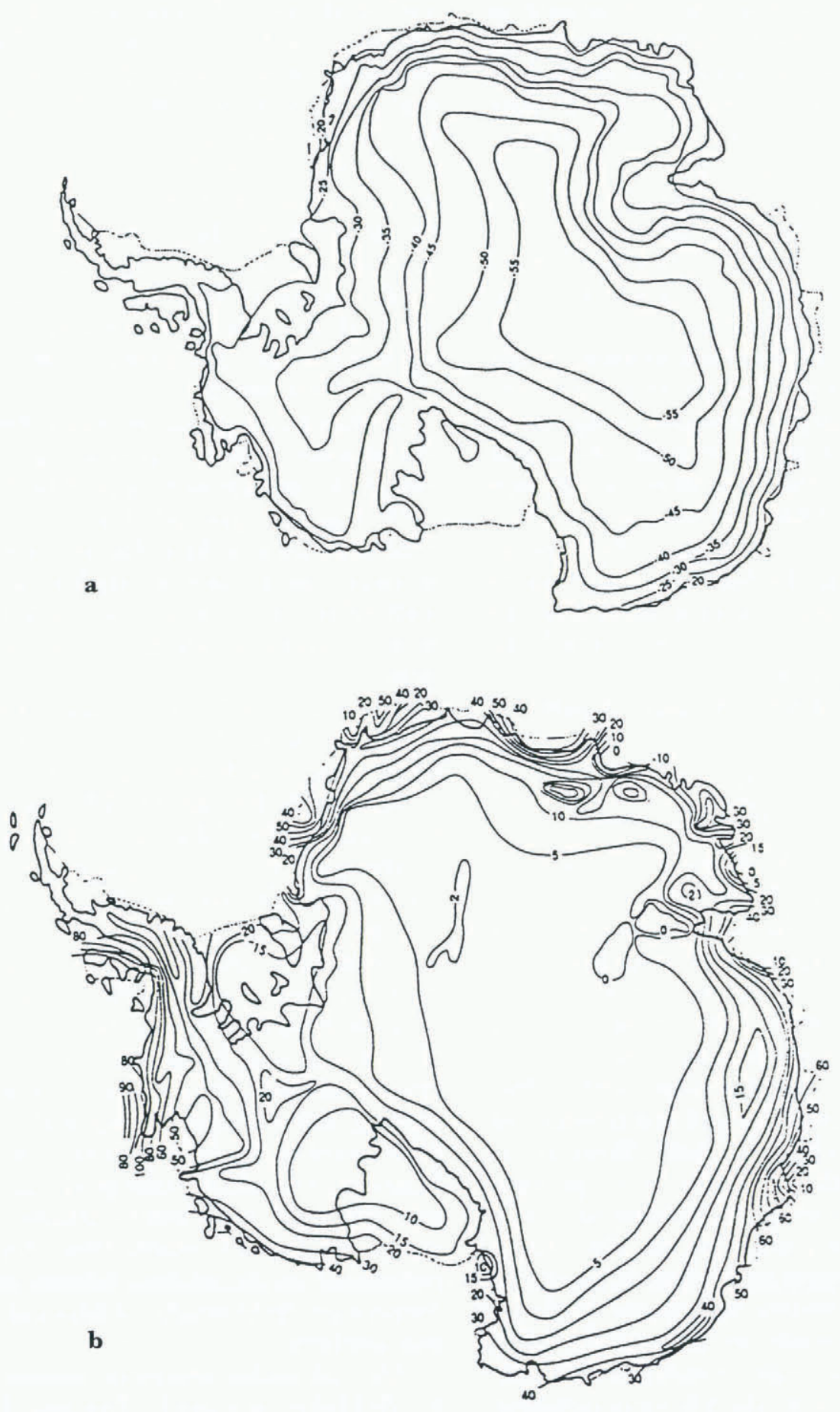

Fig. 2. (a) Mean annual ice-sheet surface temperature $\left({ }^{\circ} \mathrm{C}\right)$, based on surface measurements of Antarctica. Adapted from Robin (1983). (b) Mean annual surface mass-balance distribution on Antarctica. Values are in water equivalent cm year $^{-1}$. Adapled from Giovinetto and Bentley (1985).

\section{HEAT TRANSFER WITHIN THE ANTARCTIC ICE SHEET}

Thermal model results indicate that, using a Robin-type approach (Equation (1)), the ice-sheet base above $70 \%$ of all known subglacial lakes is at the pressure-melting temperature when a geothermal heat flux of $54 \mathrm{~mW} \mathrm{~m}^{-2}$ is used as the sole component of the ice-sheet basal temperature gradient (Fig. 3). In addition, the temperature of the ice-sheet base above $75 \%$ of subglacial lakes was calculated within $1^{\circ} \mathrm{C}$ of the pressure-melting point (Fig. 3). The majority of these lakes are located around the Dome C $\left(75^{\circ} \mathrm{S}, 125^{\circ} \mathrm{E}\right)$, Ridge B $\left(77^{\circ} \mathrm{S}, 92^{\circ} \mathrm{E}\right)$ and Vostok station $\left(78^{\circ} \mathrm{S}, 105^{\circ} \mathrm{E}\right)$ regions of East Antarctica (Fig. 4). At Titan Dome $\left(88^{\circ} \mathrm{S}, 140^{\circ} \mathrm{E}\right)$ and Talos Dome $\left(73^{\circ} \mathrm{S}, 157^{\circ} \mathrm{E}\right)$, where several subglacial lakes exist, the temperature of the ice-sheet base above the lakes is calculated at, or within $1^{\circ} \mathrm{C}$ of, the pressure-melting temperature. However, in contrast to these relatively warm basal ice-sheet temperatures, we calculate the basal temperature above lakes located near Hercules Dome and the Whitmore Mountains to be greater than $5^{\circ} \mathrm{C}$ below the pressure-melting value (Fig. 4). Indeed, basal temperatures above lakes located, for the most part, 


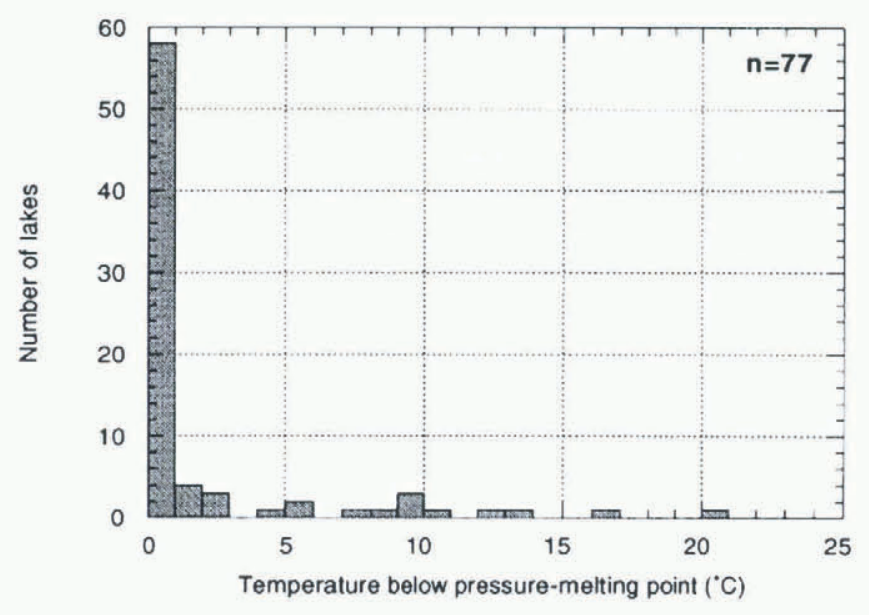

Fig. 3. Histogram indicating the theoretical basal temperature distribution above Antarctic subglacial lakes, using Equation (1) to derive $T_{\mathrm{B}}$ for each lake whilst assuming a geothermal heat flux of $54 \mathrm{~mW} \mathrm{~m}^{-2}$.

away from ice divides in Terre Adélie $\left(68^{\circ} \mathrm{S}, 137^{\circ} \mathrm{E}\right)$, George V Land $\left(70^{\circ} \mathrm{S}, 140^{\circ} \mathrm{E}\right)$ and Oates Land $\left(71^{\circ} \mathrm{S}\right.$, $\left.151^{\circ} \mathrm{E}\right)$, are calculated at $11.2-20.4^{\circ} \mathrm{C}$ below the pressure-melting temperature (Fig. 4).

By varying $\Lambda_{\text {geo }}$ until pressure melting is attained for each lake, the effective basal heat gradient required to ensure basal melting was calculated. A surrogate geothermal heat flux was thus determined which causes, in Equation (4), a basal heat gradient equivalent to that derived from the actual geothermal-heat and horizontal ice-motion terms. From this exercise, we can determine the percentage of subglacial lakes that experience melting above them, as a function of the imposed geothermal heat flux $\left(\Lambda_{\text {geo }}\right)$ (Fig. 5).

\section{Basal thermal regime around ice divides}

Consideration of the spatial distribution of subglacial lakes shows that many $(\sim 43 \%)$ are located directly over,

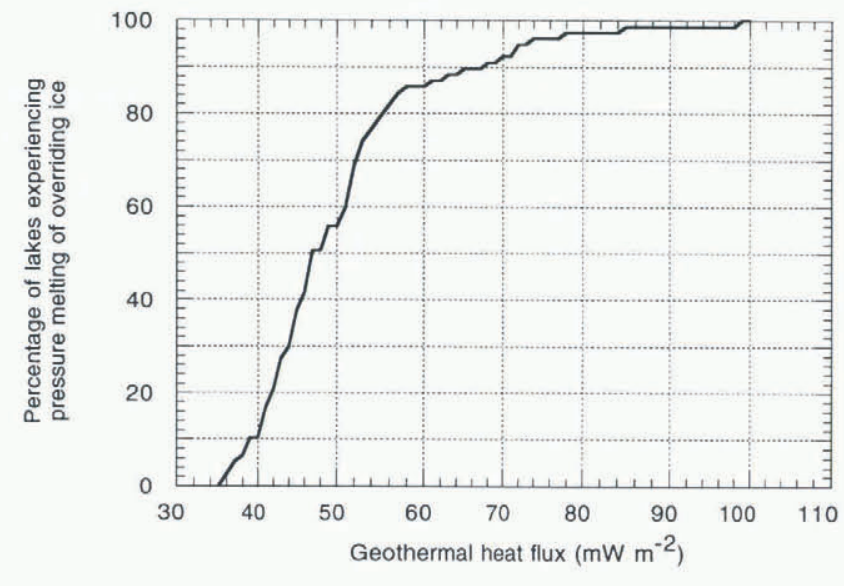

Fig. 5. Basal temperature gradient against the number of lakes experiencing pressure melting above them. The graph indicates how varying the geothermal heat flux affects the basal temperature of the ice sheet above subglacial lakes.

or relatively close $(<100 \mathrm{~km})$ to, ice divides (Figs 1 and 4). The ice sheet at and around ice divides will experience little basal heat derived from horizontal ice-motion terms. Consequently, the basal heat gradient required by Equation (1) to calculate the pressure-melting temperature above subglacial lakes located in such regions will be associated mainly with the supply of geothermal heat. We calculate this heat gradient for subglacial lakes which lie along, or close to, the ice divide. In this experiment, the minimum geothermal heat flux $\left(\Lambda_{\min }\right)$ that allows the pressure-melting temperature to be reached is calculated. Variation of the calculated minimum basal heat gradient within the ice sheet close to ice divides will, therefore, be due mainly to changes in the geothermal heat flux within the Antarctic continent.

Comparing the geographical location of those subglacial lakes which exist near to ice divides with $\Lambda_{\min }$, illustrates that the geothermal heat flux varies spatially around the Antarctic Plate (Fig, 6). For example, at

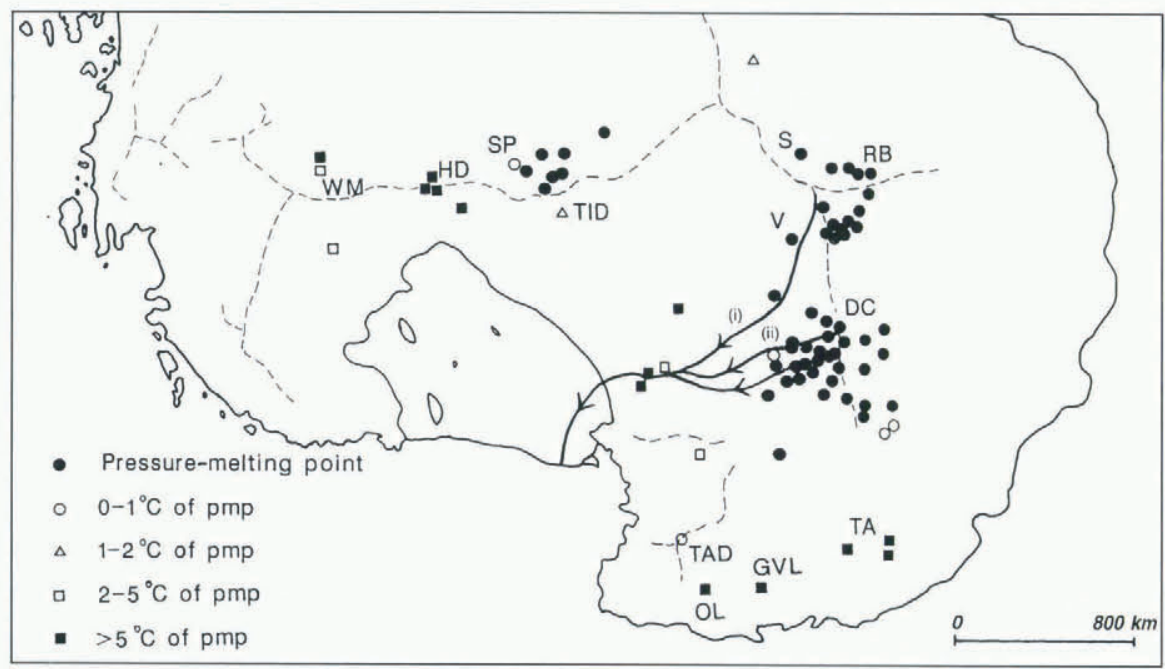

Fig. 4. Distribution of basal ice temperatures above Antarctic subglacial lakes, calculated by solving Equation (1) for $T_{\mathrm{B}}$, given $\Lambda_{\text {geo }}=54 \mathrm{mWm}^{2}$. The positions of three flowlines (solid lines with arrows) along which several subglacial lakes exist are shown (after Drewry, 1983). Information concerning the ice-sheet thermal regime along flowlines (i) and (ii) is referred to later. Abbreviations to place-names are as in Figure 1. 


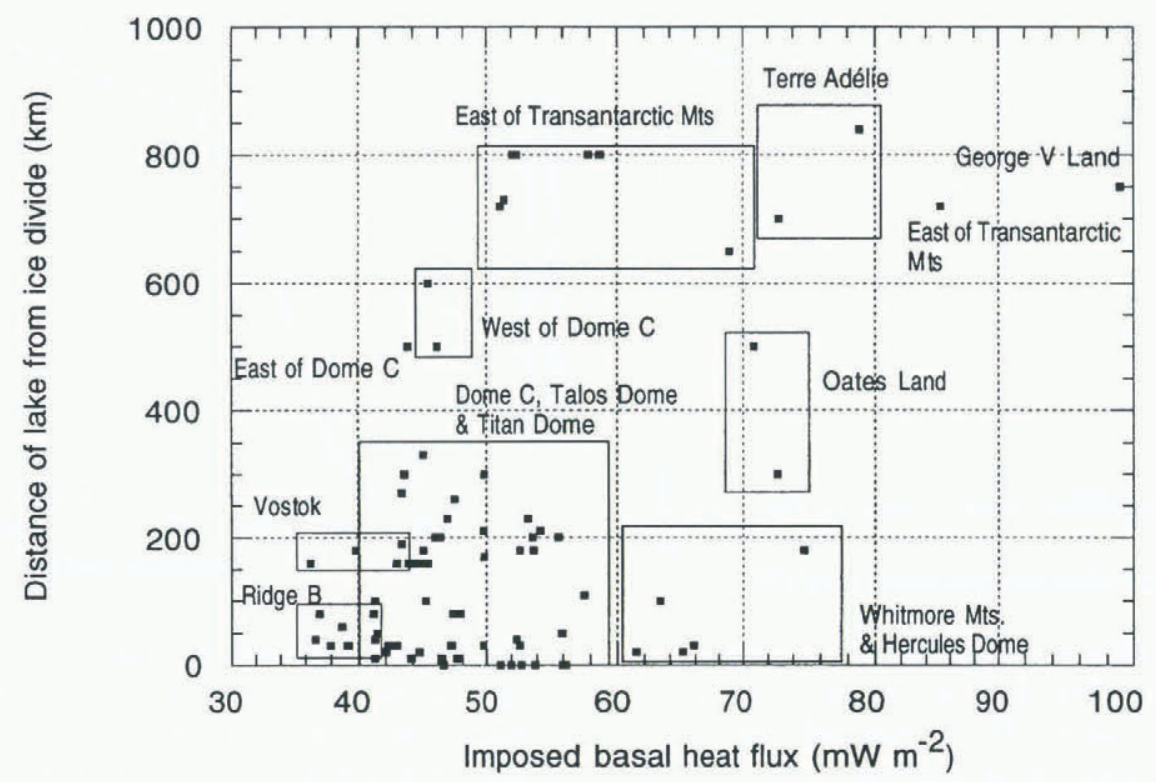

Fig. 6. Imposed basal heat flux required to induce pressure melting against the distance of the lake, along the direction of ice flow, from the nearest ice divide. Data points are identified with respect to geographical location. The graph illustrates the amount of basal heat required to ensure basal melting above subglacial lakes, and how this relates to the location of the lake within the ice sheet. See Figure 1 for locations of named regions of Antarctica.

Dome C, Talos Dome and Titan Dome, the data points illustrated in Figure 6 are tightly clustered with little variation in the minimum geothermal heat flux (41$\left.58 \mathrm{~mW} \mathrm{~m}^{-2}\right)$. However, the $\Lambda_{\min }$ around the large lake near to Vostok station appears to remain at or below $43 \mathrm{~mW} \mathrm{~m}^{-2}$, whilst at Ridge B it is $37-42 \mathrm{~mW} \mathrm{~m}^{-2}$ (Fig. 6). For lakes located around the Hercules Dome region the minimum geothermal heat flux required for basal pressure melting is consistently above $60 \mathrm{~mW} \mathrm{~m}^{-2}$ (Fig. 6). Consequently, the geothermal heat flux in the Hercules Dome region of Antarctica may be around $20-25 \mathrm{~mW} \mathrm{~m}^{-2}$ higher than that in Ridge $\mathrm{B}$, and $10-15 \mathrm{~mW} \mathrm{~m}^{-2}$ higher than in Dome C.

From our analysis of the geothermal heat properties beneath subglacial lakes, we suggest that, beneath ice divides of the East Antarctic ice sheet, the Antarctic Plate's geothermal heat flux varies between about 37 and $64 \mathrm{~mW} \mathrm{~m}^{-2}$.

It should be noted that several data points in Figure 6 relate to subglacial lakes that lie far $(>400 \mathrm{~km})$ from an ice divide. In such cases, the minimum basal heat gradient (Equation (4)) required to calculate the pressure-melting value at the ice-sheet base should be regarded as a combination of the heat derived from the Earth plus horizontal ice-motion terms (i.e. internal ice deformation and basal sliding).

\section{Basal thermal regime away from ice divides}

A number of subglacial lakes have been identified relatively far $(>400 \mathrm{~km})$ from ice divides (Figs 1 and 4). At such locations, assuming that the geothermal heat flux remains between approximately 37 and $64 \mathrm{~mW} \mathrm{~m}^{-2}$, any additional basal heat that may be required in our model to ensure pressure melting above the lakes can be attributed to (1) that delivered from horizontal advection of ice, and (2) that derived from ice deformation and basal sliding.
Basal temperatures calculated for subglacial lakes located in Terre Adélie, George V Land and Oates Land, assuming that the geothermal heat flux of $54 \mathrm{~mW} \mathrm{~m}^{-2}$ is the only source for basal heat, were calculated to be significantly $\left(>5^{\circ} \mathrm{C}\right)$ below the pressure-melting temperature (Fig. 4). In order for the ice-sheet base to attain the pressure-melting point over these lakes, the heat transported by horizontal advection and produced by horizontal ice-motion terms should negate the loss of heat due to vertical heat flow.

In order to determine the amount of heat required from horizontal ice-flow terms to maintain the basal temperature of the Antarctic ice sheet at the pressuremelting point above known subglacial lakes, results from our experiment to determine the minimum geothermal heat flux $\left(\Lambda_{\min }\right.$; i.e. solving Equation (1) for $\left.\Lambda_{\text {geo }}\right)$ are relevant. For each lake, the minimum effective basal heat gradient (representing the actual sum of geothermal flux and heat formed through horizontal ice motion) that would produce pressure melting at the ice-sheet base was determined (Fig. 6).

Heat transported by the horizontal advection of ice and that resulting from internal ice deformation and basal sliding will generally increase with ice velocity and, therefore, with distance from an ice divide. The minimum effective basal heat gradient that was calculated in order to attain pressure melting above each lake was compared with the distance from each lake along a flowline from the nearest ice divide (Fig. 6). The resulting graph indicates little overall correlation within the data set. However, when the data are segmented into geographical locations, groupings of lake locations become apparent. We interpret Figure 6 to be an indication of either (a) the spatial variation in geothermal heat flux beneath identified regions of Antarctica (for lakes which lie over an ice divide), (b) a representation of the distribution of heat due to horizontal ice-velocity components within the ice sheet 
(assuming a constant geothermal heat flux at around $54 \mathrm{~mW} \mathrm{~m}^{-2}$ ), or (c) a combination of the two.

Assuming that the geothermal heat flux remains constant at $54 \mathrm{~mW} \mathrm{~m}^{-2}$, we calculate that the additional heat (from horizontal ice-motion terms) required to produce pressure melting at the ice-sheet base within George V Land and Terre Adélie is on the order of about a further $25-50 \mathrm{~mW} \mathrm{~m}^{-2}$ of equivalent geothermal heat. Similarly, in Oates Land the heat produced through horizontal ice motion is likely to compare with an equivalent additional geothermal heat flux of $20 \mathrm{~mW} \mathrm{~m}^{-2}$ (Fig. 6).

\section{Heat transfer along ice-sheet flowlines}

A number of subglacial lakes are located along several flowlines within the Antarctic ice sheet (Fig. 4). Two such flowlines were identified as having subglacial lakes located both close to, and far from, the ice divide. The surrogate geothermal conditons required to calculate basal melting above these lakes provide an indication of the variation in the heat derived from horizontal icemotion terms along the flowline (assuming a steady geothermal heat flux). The basal ice-sheet temperatures above subglacial lakes within two ice flowlines were studied (Fig. 4). Five subglacial lakes were identified along a transect from Dome C to east of the Transantarctic Mountains (situated 0, 200, 270, 600 and $800 \mathrm{~km}$ from the divide), whilst six lakes were identified along a flowline from Ridge B to east of the Transantarctic Mountains (located 30, 180, 190, 600, 610 and $1200 \mathrm{~km}$ from the divide).

The distance to the ice divide was plotted against the value of the minimum basal heat flux $\left(\Lambda_{\min }\right)$ required to produce basal melting above subglacial lakes for both flowlines (Fig. 7). If we assume that the actual geothermal

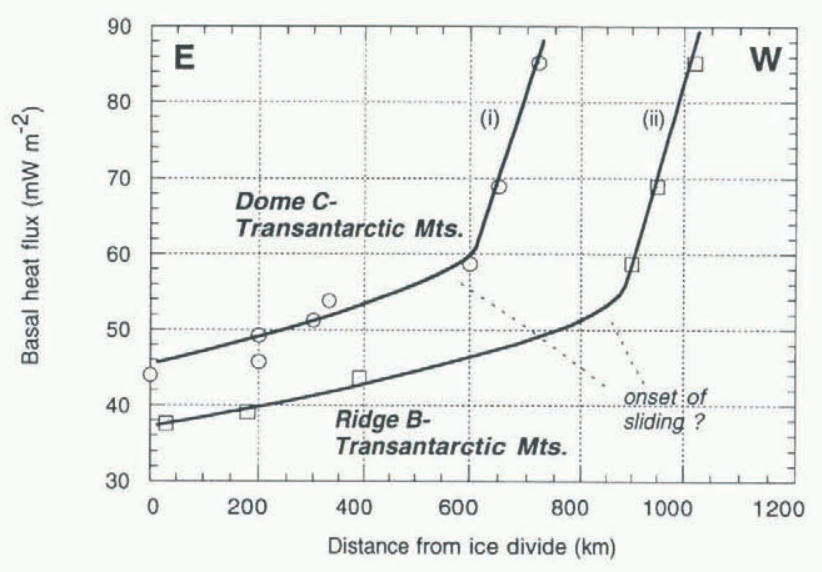

Fig. 7. Basal heat flux required to model the pressuremelting temperature above subglacial lakes, with distance from the ice divide along two ice flowlines. The graph illustrates the variation in basal thermal heat transfer along east-west flowlines from (i) Ridge $B$ and (ii) Dome C, to east of the Transantarctic Mountains (locations of the flowlines are provided in Figure 4). Note that, because the flowlines converge towards the Transantarctic Mountains, the final three data points used in both flowlines are the same. heat flux $\left(\Lambda_{\text {geo }}\right)$ remains steady along the flowline, then variation in $\Lambda_{\min }$ above $54 \mathrm{~mW} \mathrm{~m}^{2}$ will be due to heat terms other than that derived from the Earth. Thus, the resulting best-fit curves in Figure 7 (exponential-type functions) represent empirical relations between the distance from the ice divide and the amount of heat due to horizontal ice-motion terms along the flowlines indicated. From this, the manner in which the vertical effective basal heat gradient varies horizontally along the flowline can be determined (Fig. 7). A rapid increase in the effective basal heat gradient can be observed at $600 \mathrm{~km}$ along the flowline from Dome C, and $900 \mathrm{~km}$ along that from Ridge B (Fig. 7). Downstream from the locations at which these thermal transitions occur, the effective basal heat gradient can be observed to increase pseudo-linearly with distance. A possible explanation for this change in the basal temperature gradient is that it marks the onset of significant sliding at the ice-sheet base. Hence, the thermal transition separates regions of the ice sheet where the vertical effective basal heat gradient receives little input from glacier sliding and those in which the heat derived from basal sliding dominates the basal heat gradient.

Unfortunately, the absence of other associations between individual ice flowlines and subglacial lake locations precludes our investigation of the heat derived from horizontal ice motion for other regions of the ice sheet.

\section{COMPARISON WITH GLACIOLOGICAL MODELLING INFORMATION}

Glaciological modelling can be used to calculate the temperature of the ice-sheet base by a procedure different to that employed in this study. It is useful, therefore, to compare our results with those determined from previous modelling investigations of the Antarctic ice sheet. We examine the results of two independent glaciological modelling studies, namely the thermomechanic studies of Budd and Jenssen (1989) and Huybrechts (1992). In both cases, the basal temperature of the ice sheet was calculated by a thermal model which accounted for heat derived from ice deformation and basal sliding. What remained largely unknown in these modelling investigations was the value for the geothermal heat flux from the Antarctic Plate. However, both studies investigated the ice-sheet response to variations within the spatially uniform geothermal heat-flux input.

Budd and Jenssen (1989) found that when a geothermal heat flux of up to $51.7 \mathrm{~mW} \mathrm{~m}^{-2}$ was used, the centre of the ice sheet at Dome C, Ridge B and the South Pole experienced basal temperatures below the pressure-melting value. However, when the geothermal heat flux was $57.5 \mathrm{~mW} \mathrm{~m}^{-2}$, basal temperatures within the region representing Dome $\mathrm{C}$ were at the pressure-melting value. Similarly, although Huybrechts (1992) generated basal melting temperatures around Dome $\mathrm{C}$ when the geothermal heat flux was $54.7 \mathrm{~mW} \mathrm{~m}^{-2}$, his model did not predict the pressure-melting temperature beneath Ridge B. In our study, we predict that basal melting over subglacial lakes in the area of Ridge B should occur even when the geothermal heat flux is reduced to around 
$43 \mathrm{~mW} \mathrm{~m}^{-2}$ (Fig. 6). The discrepancy between our results and those of the two glaciological models may be a consequence of bedrock smoothing that occurs within numerical modelling of ice sheets. We predict that the geothermal heat flux varies spatially beneath the Antarctic ice sheet between 37 and $64 \mathrm{~mW} \mathrm{~m}^{-2}$. However, to date, glaciological models have not accounted for spatial variability in geothermal heat.

Both glaciological models predicted basal melting temperatures around $80^{\circ} \mathrm{S}, 150^{\circ} \mathrm{E}$ for values of the geothermal heat flux between around $\pm 10 \%$ of $54 \mathrm{~mW} \mathrm{~m}^{2}$. This location is over $400 \mathrm{~km}$ from the nearest ice divide, and corresponds with the downstream end of the two ice flowlines analyzed in our study (Figs 1 and 4). The glaciological models predict pressure-melting values because of the relatively high basal temperature gradient in this region, which is caused by heat derived from basal sliding of the ice sheet. Upstream from this location, the basal temperature decreases to below the pressure-melting value (e.g. Fig. 1b), because of the absence of basal sliding and the heat derived from this process. Our analysis suggests that, along the two flowlines, the rapid variation within the basal heat flux may correspond with the onset of basal sliding (Fig. 7). We consider there to be good agreement between our independent analysis of the basal thermal properties along these two flowlines within the East Antarctic ice sheet and glaciological model results from this same region.

\section{SUMMARY AND CONCLUSIONS}

A one-dimensional vertical heat-transfer equation (Robin, 1955) was used to analyze the thermal regime of the Antarctic ice sheet above known subglacial lakes. Three inputs to this thermal equation (Equation (1)) were provided by existing Antarctic field measurements (i.e. ice thickness $(h)$, surface accumulation $(b)$ and surface temperature $\left.\left(T_{\mathrm{S}}\right)\right)$. A fourth variable, the basal ice temperature above subglacial lakes $\left(T_{\mathrm{B}}\right)$, was assumed to be equal to the pressure-melting value. Equation (1) was subsequently solved for $\Lambda_{\text {geo }}$, the geothermal heat input. In addition, assuming a value for the geothermal heat-flux input, Equation (1) was solved for $T_{\mathrm{B}}$. Results from the numerical experiments indicated the following points about the thermal regime of the Antarctic ice sheet above subglacial lakes.

1. The temperature at the base of the Antarctic ice sheet was modelled to be at pressure-melting over about $70 \%$ of the subglacial lakes (which are located in the regions of Dome C, Ridge B and Vostok station) when using a geothermal heat flux of $54 \mathrm{~mW} \mathrm{~m}^{-2}$.

2. The geothermal heat flux was calculated to determine the minimum basal heat required to produce basal melting of the ice sheet above all lakes (Equation (4)). The minimum heat flux was $40 \mathrm{~mW} \mathrm{~m}^{-2}$ when eight lakes out of the whole data set experienced basal melting above them (Fig. 5). Conversely, the icesheet base over only one lake (in George V Land) remained below the pressure-melting value when the minimum geothermal flux of heat was $90 \mathrm{~mW} \mathrm{~m}^{-2}$ (Fig. 5).
3. The amount of additional basal heat required to melt the ice-sheet base over a number of lakes was found to be related strongly to the geographical location of the lakes (Fig. 6).

4. The additional heat can be derived either geothermally (requiring a substantial spatial variability in the geothermal heat flux within Antarctica) or from horizontal basal sliding and internal ice deformation (or through a combination of the two).

5. Near $(<100 \mathrm{~km})$ to ice divides, where a high concentration $(\sim 43 \%)$ of lakes exists, since the horizontal advection of ice should be relatively small, the geothermal heat flux calculated to ensure basal melting of the ice sheet was $37-64 \mathrm{~mW} \mathrm{~m}^{-2}$. However, away from the ice divide at Terre Adélie, where horizontal advection may be relatively high, the effective basal heat flux required to ensure pressure melting at the ice-sheet base was 1.5-2 times the value needed at Dome C. Subsequently, heat derived from ice flow at Terre Adélie may be of the same order as the heat flux derived from the Earth.

6. Plotting the effective basal heat flux (required to calculate basal melting above sub-ice lakes) against the distance of the lake to the nearest ice divide, provides information on the variation in heat derived from horizontal ice-motion terms along the flowline. Two such flowlines were investigated, between the ice margin east of the Transantarctic Mountains and (a) Dome $\mathrm{C}$ ice divide and (b) Ridge $\mathrm{B}$ ice divide. In both cases, we parameterize empirically the variation of heat due to horizontal ice motion along the flowline as an exponential-type relation. The location along the flowline at which a significant rise in the effective basal heat flux occurs may correspond to the onset of basal sliding (Fig. 7).

\section{ACKNOWLEDGEMENTS}

Funding for this project was provided by U.K. Natural Environment Research Council grant GR9/1418. We thank Dr C.S. M. Doake for commenting on a draft of this paper, referees for providing constructive reviews and the Director of the Scott Polar Research Institute for his support of this project.

\section{REFERENCES}

Bogorodskiy, V. V., C. R. Bentley and P.E. Gudmandsen. 1985. Radioglaciology. Dordrecht, D. Reidel Publishing Co.

Budd, W.F. and D. Jenssen. 1989. The dynamics of the Antarctic ice sheet. Ann. Glaciol., 12, 16-22.

Drewry, D.J., ed. 1983. Antarctic: glaciological and geophysical folio. Cambridge, Scott Polar Research Institute.

Fortuin, J. P.F. and J. Oerlemans. 1990. Parameterization of the annual surface temperature and mass balance of Antarctica. Ann. Glaciol., 14, 7884.

Giovinetto, M. B. and C.R. Bentley, 1985. Surface balance in ice drainage systems of Antarctica. Antarct. J. U.S., 20 (4), 6-13.

Huybrechts, P. 1992. The Antarctic ice sheet and environmental change: a three-dimensional modelling study. Ber. Polarforsch. 99.

Jenssen, D. and J. A. Campbell. 1983. Heat conduction studies. In 
Robin, G. de Q., ed. The climatic record in polar ice sheets. Cambridge, etc., Cambridge University Press, 125-138.

Kapitsa, A. P., J.K. Ridley, G. de Q. Robin, M.J. Siegert and I. A. Zotikov. 1996. A large deep freshwater lake beneath the ice of central East Antarctica. Nature, 381 (6584), 684686.

Loewe, F. 1970. Screen temperatures and $10 \mathrm{~m}$ temperatures. J. Glaciol., $9(56), 263-268$.

McIntyre, N. F. 1983. The topography and flow of the Antarctic ice sheet. (Ph.D. thesis, University of Cambridge.)

Oswald, G. K.A. and G. de Q. Robin. 1973. Lakes beneath the Antarctic ice sheet. Nature, 245 (5423), 251-254.

Paterson, W. S. B. 1994. The physics of glaciers. Third edition. Oxford, etc. Elsevier.
Robin, G.de Q. 1955. Ice movement and temperature distribution in glaciers and ice sheets. J. Glaciol., 2(18), 523-532.

Robin, G. de Q., ed. 1983. The climatic record in polar ice sheets. Cambridge, etc., Cambridge University Press.

Robin, G. de Q., D. J. Drewry and D. T. Meldrum. 1977. International studies of ice sheet and bedrock. Philos. Trans. R. Soc. London, Ser. B, 279 (963), 185-196.

Siegert, M.J., J. A. Dowdeswell, M. R. Gorman and N. F. McIntyre. In press. An inventory of Antarctic sub-glacial lakes. Antarct. Sit.

Stacey, F.D. 1977. Physics of the Earth. Second edition. New York, John Wiley and Sons.

Whillans, I. M. 1978. Inland ice sheet thinning due to Holocene warmth. Science, 201(4360), 1014-1016.

MS received 26 January 1996 and accepted in revised form 14 May 1996 